\title{
The Albert silver mine and trippkeite occurrence, Mpumalanga, South Africa
}

Paul M.P.B. Meulenbeld, Department of Water Affairs PO Box 1675 Bronkhorstspruit South Africa, meulenbeldp@dwa.gov.za.

Wiebke Grote, Department of Geology University of Pretoria, Private bag X20 Hatfield, Pretoria 0028, Wiebke.Grote@up.ac.za

Sabine Verryn, XRD Analytical \& Consulting, Pretoria, 75 Kafue street Lynnwood Glen, 0081, sabine.verryn@xrd.ac.za

Dr. Paul M.P.B. Meulenbeld is a scientific manager with the Department of Water Affairs, a trained geophysicist and mineral collector. He has a sound knowledge about southern Africa's mineral deposits and visits abandoned mines in his spare time. One of his last remarkable discoveries was the occurrence of chapmanite at the old Argent silver and lead deposit, Delmas, Mpumalanga, South Africa.

Wiebke Grote is responsible for XRD analysis at the Department of Geology, University of Pretoria where prior to this position she was the curator of the geological museum at the same institution.

Dr. Sabine Verryn is the owner of XRD Analytical \& Consulting. She is the current Vice chair of the Mineralogical Association of South Africa.

\section{INTRODUCTION}

Around 1885 the ore deposit of the Albert Silver mine was discovered and production continued intermittently until 1914 (Robb, Robb, and Walraven 1994). The Albert Silver mine is situated on the farm Roodepoortjie 250JR, north of Bronkhorstspruit, some $80 \mathrm{~km}$ east-northeast of Pretoria in Mpumalanga, South Africa (Figure 1) (Robb, Robb, and Walraven 1994). No detailed description of the mine is known to have been published, but a layout plan and a plan indicating the extent of the underground workings (Figure 2), amongst a surface geophysical study of the ore bodies was given by Van Zijl (1965). The old workings took the form of two development drives along the strike of the lode at the 23 meter and 47 meter levels below surface, together with a number of raises and winzes which passed the mineral alteration zone (Champion 1970). The mine is situated on and close to the southeastern bank of the Moos River. The topography is undulating countryside with gentle hills and granite outcrops, where depressions are caused by intrusions, mostly diabase.

The mine produced high grades of silver from 1885 till 1899 and then intermittently until 1914 (Robb, Robb, and Walraven 1994). During production the mine's ore was high-graded and yielded an estimated 20000 tonnes of ore at 1.14 kilogram per ton silver and 10 percent copper. Results from exploration after the 1950's indicated ore reserves to a depth of 150 meter to be around 1.2 Million tonnes at 73 gram per ton silver, 0.42 percent copper and 0.27 percent lead (Robb, Robb, and Walraven 1994). The history of the mine is very well documented in the work of Reeks (2012).

The mine was visited during February 2013 after some investigations about its locality and access. The mine's locality was confirmed by the use of various maps (topographic and geological) and Google Earth imaginary and an understanding of the area based on previous field work in this region. 


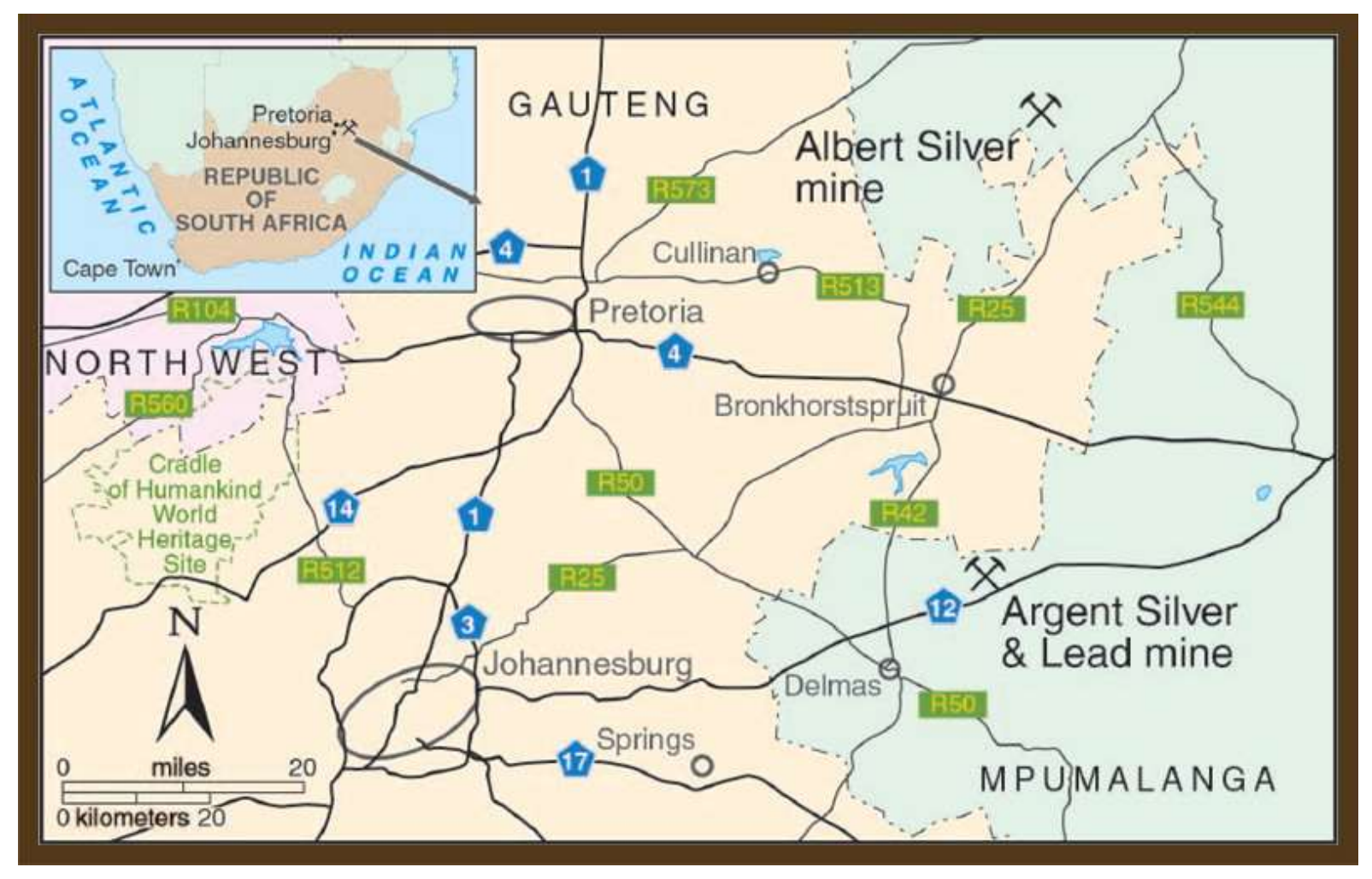

Figure 1. Locality map of the Albert Silver mine, South Africa, prepared by William W Besse.

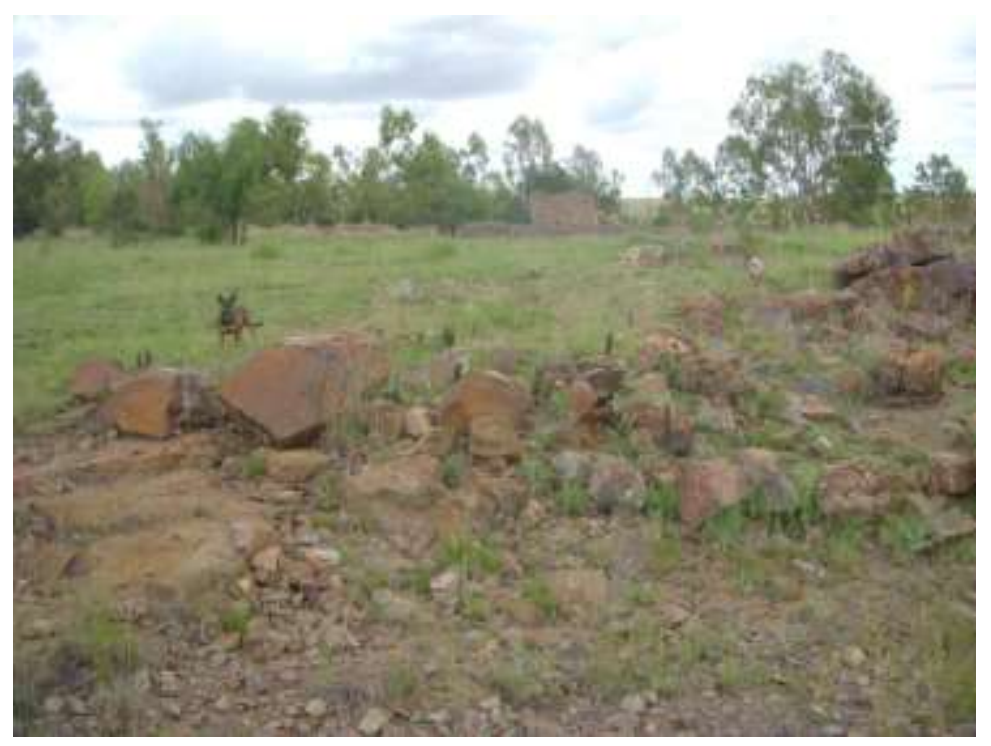

Figure 2 The Albert lode and Shaft 1 in the background.

Currently the mine workings are flooded and make mineral collection impossible within the mine. Only the mine dumps are accessible, or where the Albert lode crops out and around the entrance portals to the shafts (Figure 2). The mine is located remotely on private land, which restricts access. 


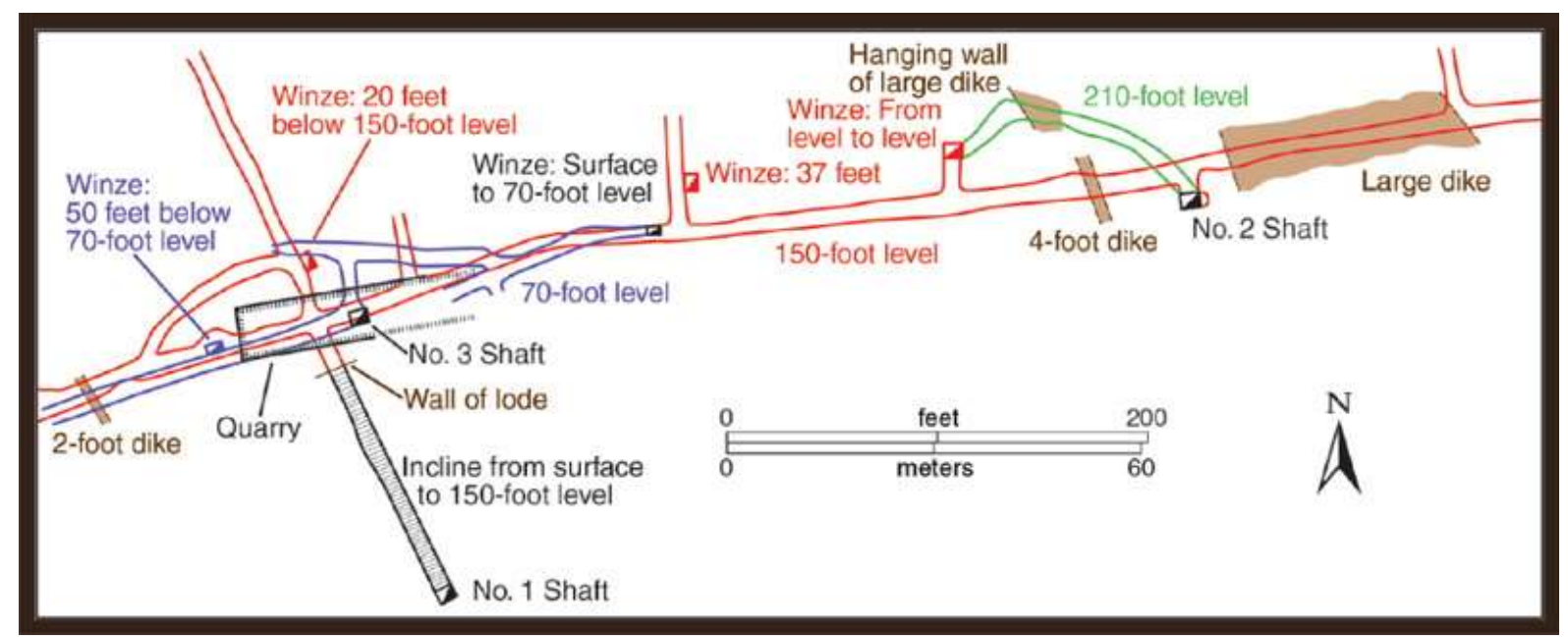

Figure 3. Plan of the underground workings at the Albert Silver mine based on Van Zijl (1965), prepared by William Besse.

\section{GEOLOGY}

The ore deposit occurs in an east-west trending, 700 meter wide fissure-zone of vertical quartz veins in pink to grey porphyritic Bushveld Igneous Complex granite, namely the Nebo Granite of the Lebowa Granite Suite. The margins of the fissure-zone are marked on surface by gossans up to about 15 meters wide (Figure 4). The zone is laterally displaced along a northwest-trending diabase dike in

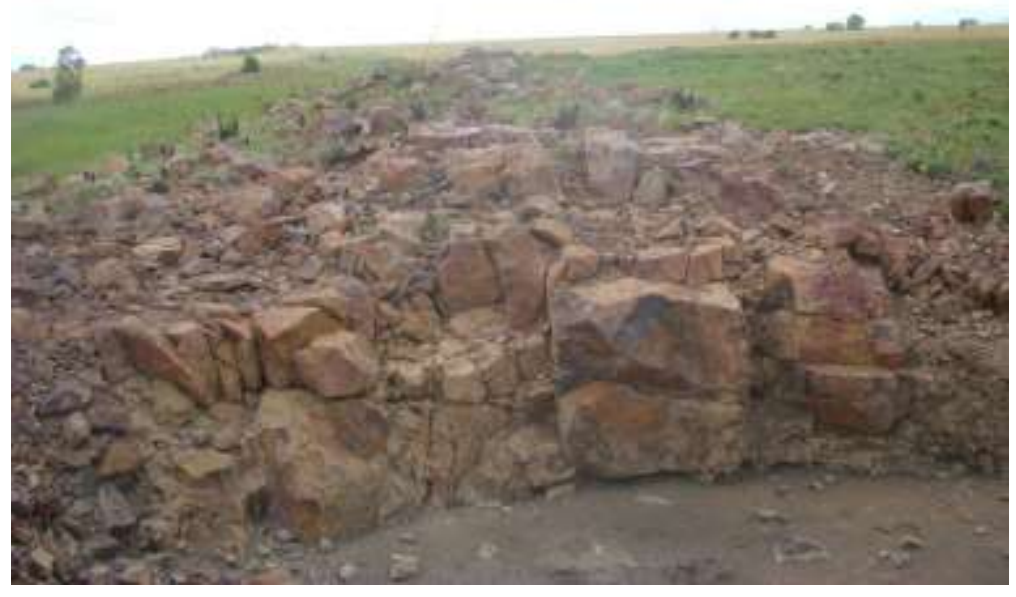

Figure 4. The Albert lode. Photo by Paul Meulenbeld.

the sub-surface (Van Zijl 1965), as displayed in Figure 5 from another locality on surface (road cut). This dike divides the Albert lode into a western and an eastern sector. In addition to the Albert lode there are the minor intermediate lodes and a Northern lode, which has a high uranium-hematite content (Champion 1970). The presence of uranium was indicated by a radiation counter (Figure 6). The mineralized veins are macroscopically characterized by an increase in the amount of quartz and 


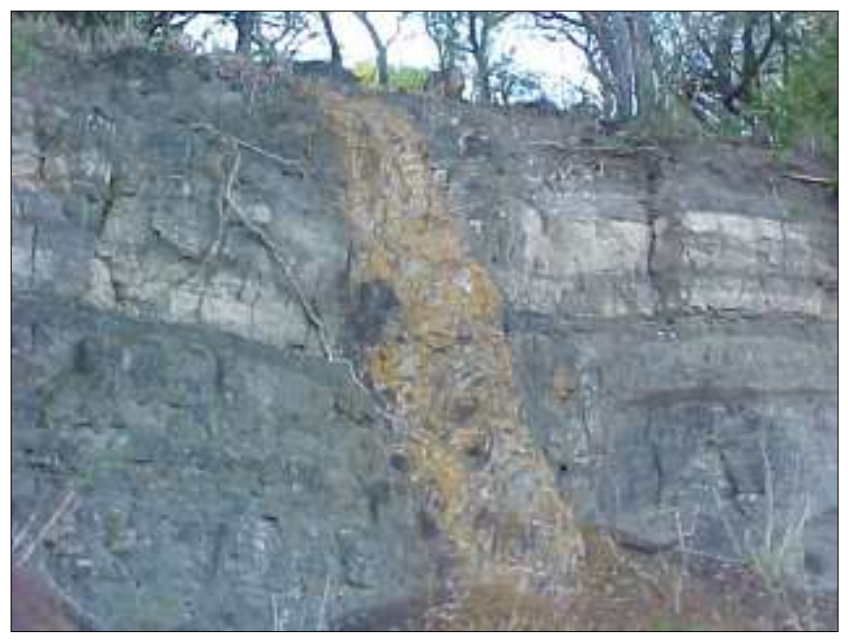

Figure 5. A shale layer laterally displaced by a diabase dike, Ithala Nature Reserve, Louwsburg, KwaZulu-Natal, South Africa. Photo by Paul Meulenbeld.

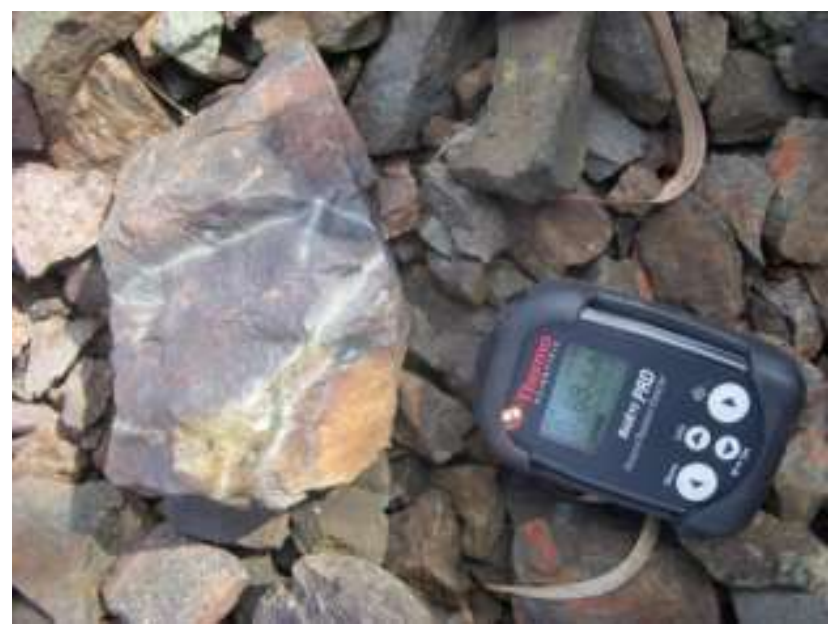

Figure 6. The presence of uranium indicated by an instant reading of $0.69 \mu$ Sieverts/hour. Photo by Paul Meulenbeld.

the disappearance of feldspar relative to quartz (Van Zijl 1965). However, at the surface very little can be seen of the ore bodies.

The Albert Lode crops out most prominently in the immediate vicinity of the Moos River where it stands out as a resistant barrier to erosion when compared with the altered granite along its northern flank. Along the southern flank of the ore body the lode rises only about 0.3 meters above the general surface level. However on the northern flank, overlooking the river, the lode consists predominantly of quartz and hematite and rises to over 2 metres above the granite of the flanking alteration zone which has been highly weathered and eroded by the action of the nearby river (Champion 1970), such as at Shaft 3 (Figure 7). 


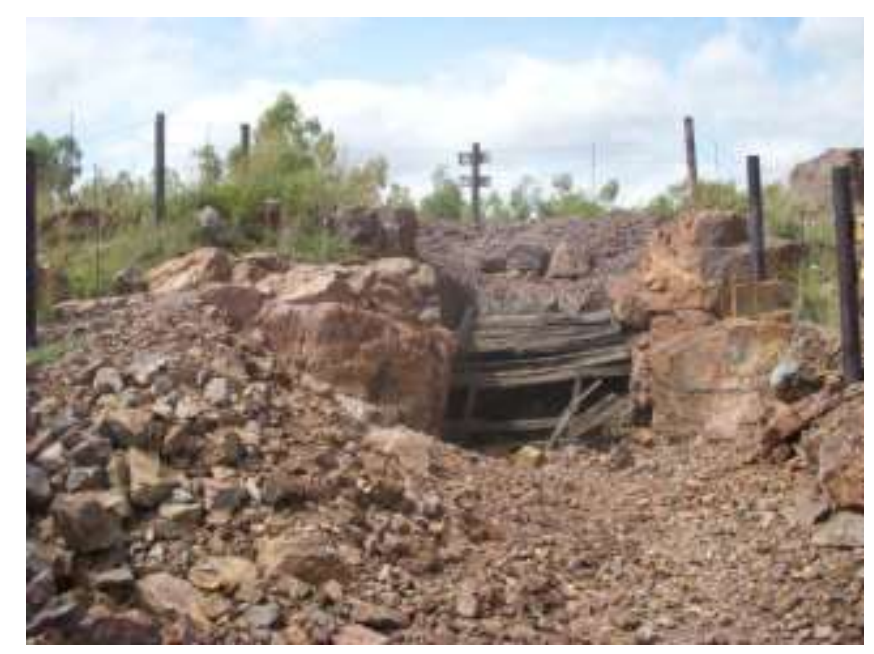

Figure 7. Shaft 3 into the Albert lode. Note the secondary copper mineralization (green colour) on the lode. Photo by Paul Meulenbeld.

According to Champion (1970) the lode continues as a prominent, slightly projecting body over a distance of about 150 meters east and 50 meters west of the river. To the west the ore body splits into a number of closely spaced hematite and quartz-hematite veins separated by layers of altered country rock. The western extremity of the body is not prominently exposed but the minor veins are easily located due to the rocky nature of the steep slope leading down to the river. Some of the many barren cross-cutting quartz veins which traverse the area are well exposed in this area. These bodies are coarsely crystalline and probably relate to the transverse dislocations that have occurred at a stage subsequent to mineralization. The cross-cutting veins consist of successive paired layers of coarse grained quartz which gives the rock a sutured appearance.

The mineral assemblage comprises copper, silver, lead, antimony and uranium. Copper and silver are the most abundant. Uranium occurs as micro-crystals of uraninite, together with quartz, magnetite, hematite and purple fluorite, a unique association in the Bushveld metallogenic province (Champion 1970 and Martini \& Vorster 1994). The principal sulphides in order of abundance are bornite, pyrite, chalcopyrite, tetrahedrite and chalcocite (Van Zijl 1965). In addition, subordinate quantities of arsenopyrite, sphalerite, galena and jamesonite occur. Hematite is a secondary product of pyrite. The sulfide paragenetic sequence is: pyrite and arsenopyrite, sphalerite and tetrahedrite, galena and jamesonite, bornite and chalcocite, and lastly chalcopyrite. The deposit is mesothermal (Van Zijl 1965). Silver values are the highest in the western sector of the lode and are attributable partly to secondary native silver and partly to silver bearing sulphides of low tenor of hypogene origin.

\section{MINERALOGY}

Many examples of supergene enriched silver deposits are known and these include the famous bonanza deposits of the western hemisphere which extended through the United States, Mexico, Central America and along the western slopes of the South American Andes. From an extensive examination of the ore assemblage by Champion (1970) of the Albert Silver mine, it appears that the silver-bearing sulphides would be incapable of providing silver values as high as those encountered at the mine pre-1914. In addition, the discovery of argentite and native silver by Champion (1970) suggest that the silver values encountered partly owe their existence to supergene enrichment. The 
kind of mineralization of the Albert Silver mine has closely followed those described for the more famous supergene enriched silver deposits of the western hemisphere such as Zacatecas, Mexico and Chañarcillo, Chile. Structurally the Albert Silver mine has followed the same sequence of events as Chañarcillo in that the ore bearing veins of hypogene origin have been reopened during periods of displacement, thus permitting erosion and weathering to redistribute the silver minerals in the lode. The best examples of supergene leaching and enrichment are to be found in pyrite-bearing silver and copper deposits (Park and McDiarmid 1963).

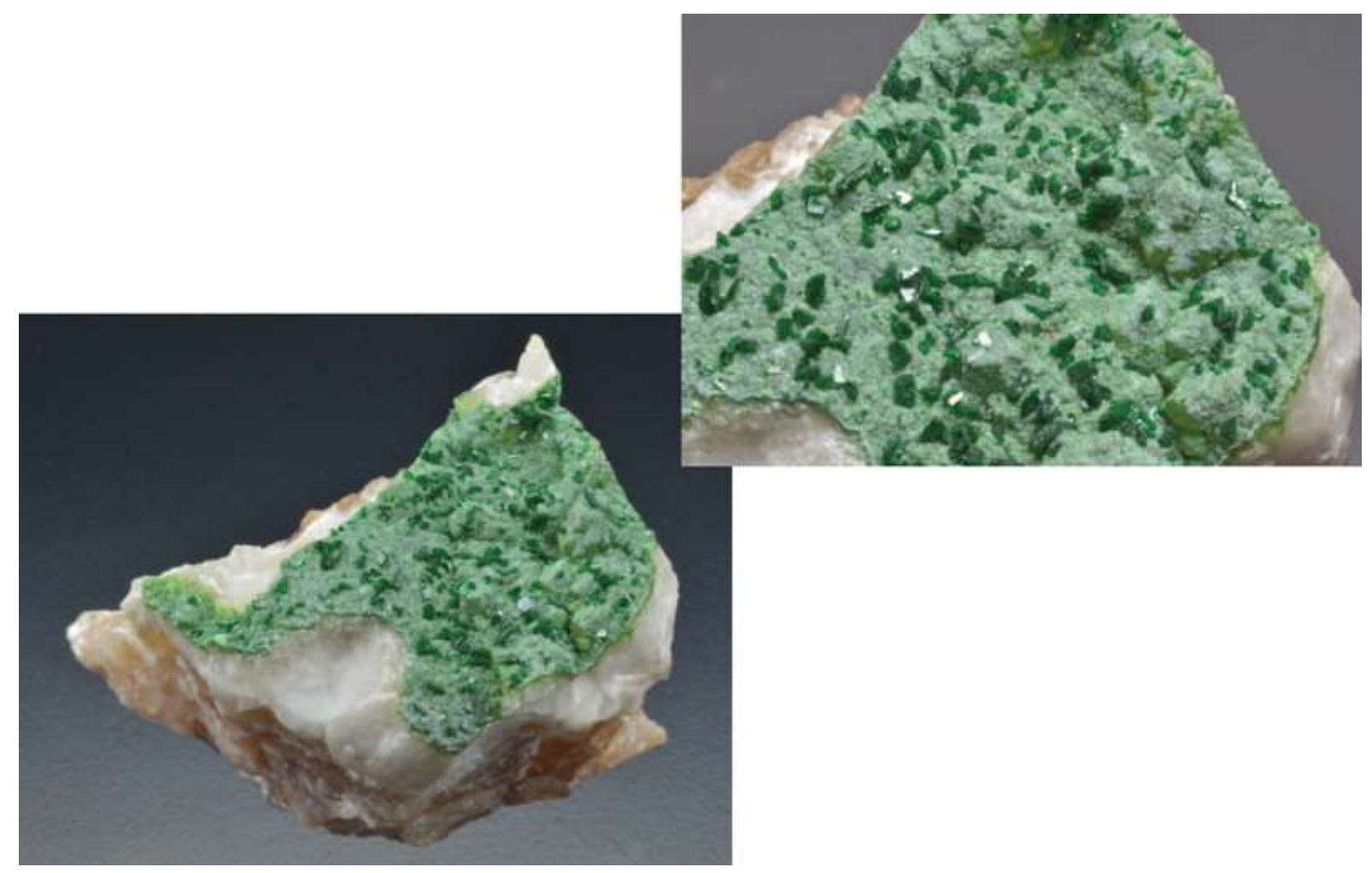

Figure 8. Trippkeite (light green) and malachite (dark green needles), Bou Azzer, Morocco. Paul Meulenbeld specimen. 22 $\times 26 \times 38 \mathrm{~mm}$. Photo by Bruce Cairncross.

The presence of trippkeite in association with malachite is only known from Bou Azzer, Morocco (Favreau et al. 2007) as represented in one of the author's (Paul Meulenbeld) mineral collection (Figure 8). The association is not similar as the malachite is a distinct later generation cover on the trippkeite, whereas at the Albert Silver mine the minerals are a mixture of each other and responsible for the light green coating in and on quartz crystals (Figure 9) and the quartz-trippkeite-malachite are encountered in the Albert lode (hematite dominated). However, the Co-Ni-As mineralization at Bou Azzer is associated with serpentinites, dolomite, granite, gabbro and quartz diorite along various secondary structures like faults and brecciated zones (Favreau et al. 2007) and distinctly different from the Albert Silver mine. 


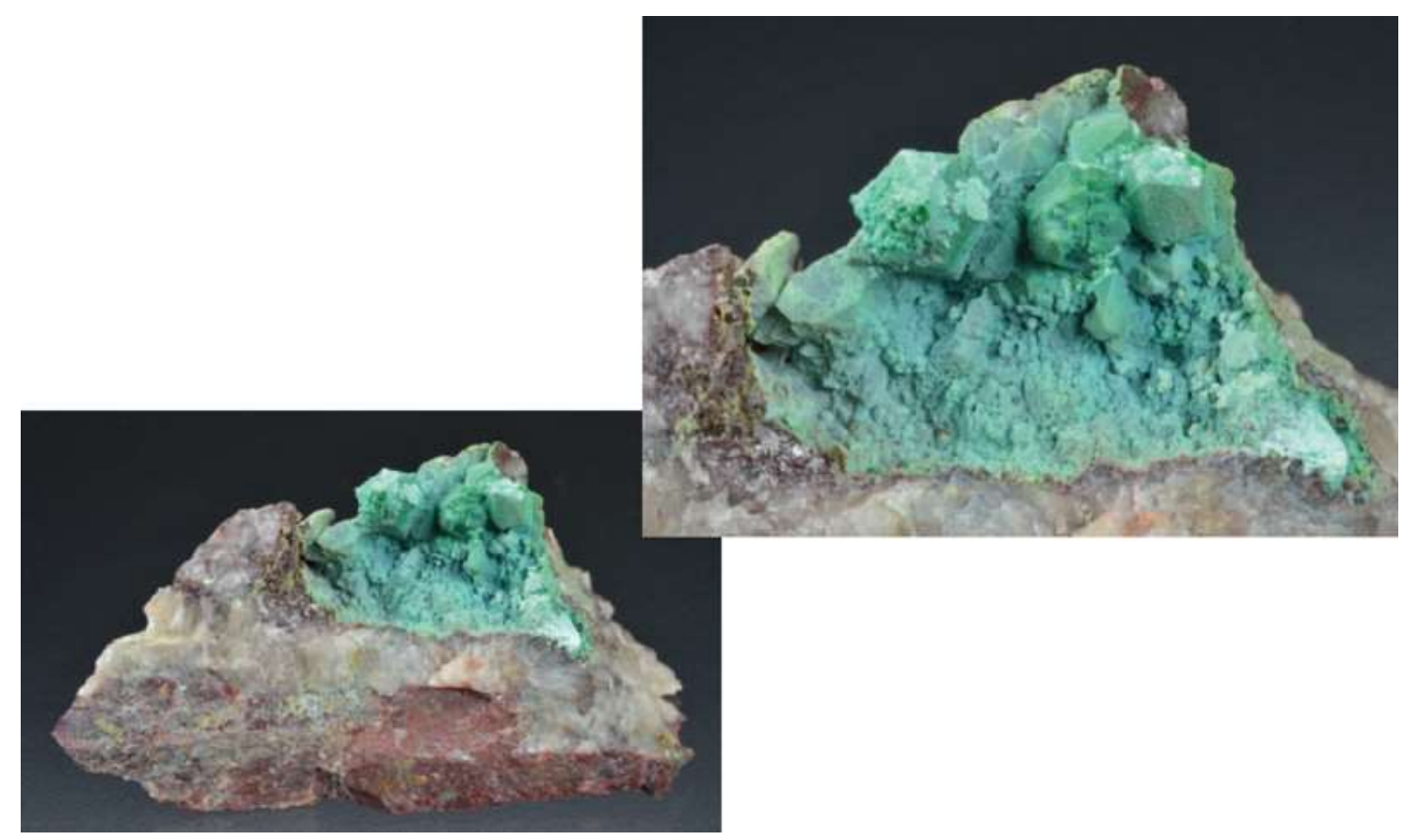

Figure 9. Trippkeite and malachite mixture, Albert Silver mine, South Africa. Paul Meulenbeld specimen $.37 \times 46 \times 70$ $\mathrm{mm}$. Photo by Bruce Cairncross.

The inclusion of distinct hematite colouring within quartz crystals (Figure 10) is similar to quartz crystals associated with the Messina (Musina) Copper Mines, Limpopo, South Africa (Cairncross 1991).

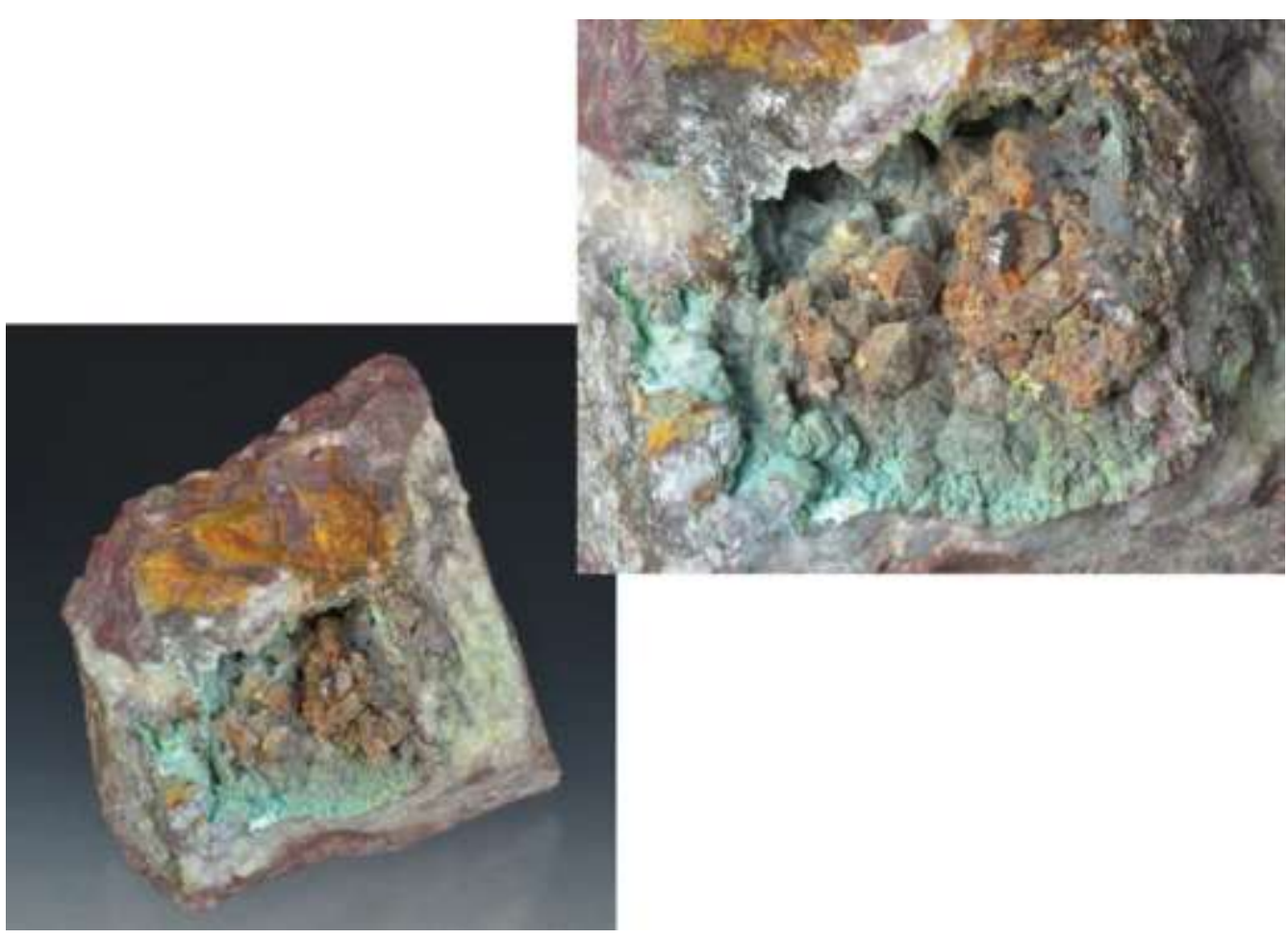

Figure 10. Hematite inclusions in quartz (red colour) with minor trippkeite and malachite coatings on smaller quartz crystals, Albert Silver mine, South Africa. Paul Meulenbeld specimen. $64 \times 65 \times 86 \mathrm{~mm}$. Photo by Bruce Cairncross. 
The mineral samples collected during the February 2013 visit were subsequently analyzed by X-Ray diffraction (XRD) at both the Geology Department at the University of Pretoria and at XRD Analytical \& Consulting. The XRD analyses revealed numerous secondary copper minerals in association with sulfates and arsenates, for example linarite (Figure 11), as in previous studies by Van Zijl (1965), Champion (1970) and Cairncross and Dixon (1995) the contribution of sulfide and arsenic to the formation of secondary minerals was less obvious. These mineral assemblages indicate that the Albert Silver mine is also a source of arsenic, which is not common in South Africa's mineral deposits. The XRD confirmation regarding the presence of trippkeite is presented in Figure 12.

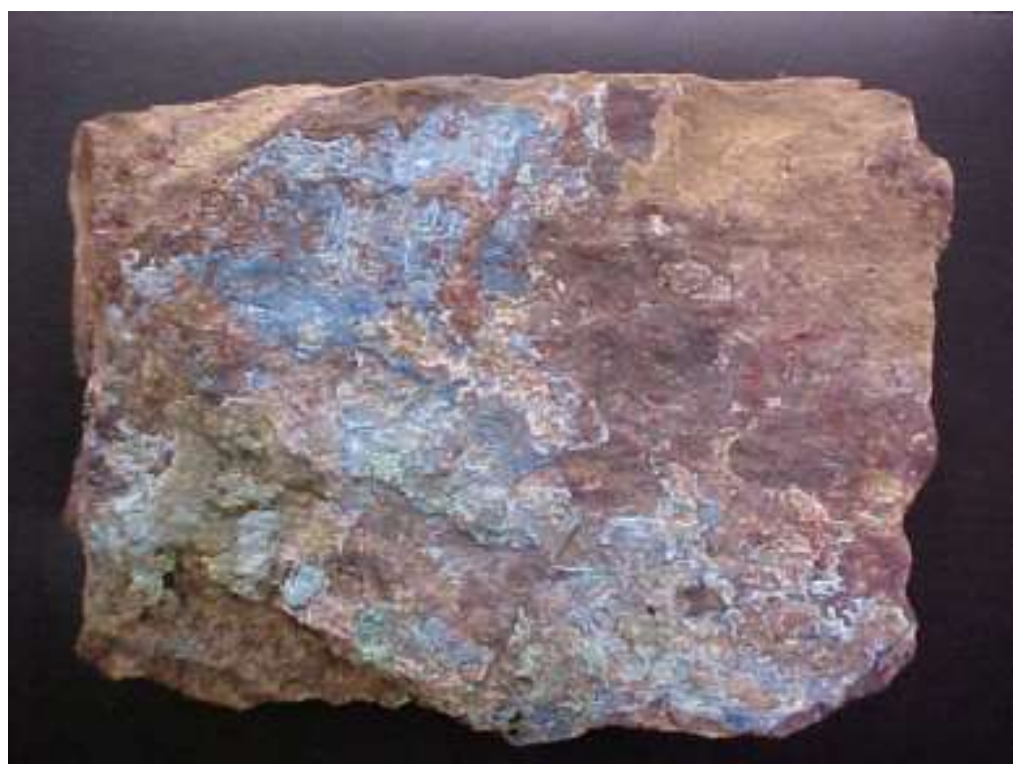

Figure 11. Linarite (light blue) and brochantite (light green) with minor clinoclase on a fragment of the Albert lode, Albert Silver mine, South Africa. Paul Meulenbeld specimen. $56 \times 103 \times 136 \mathrm{~mm}$. Photo by Bruce Cairncross.

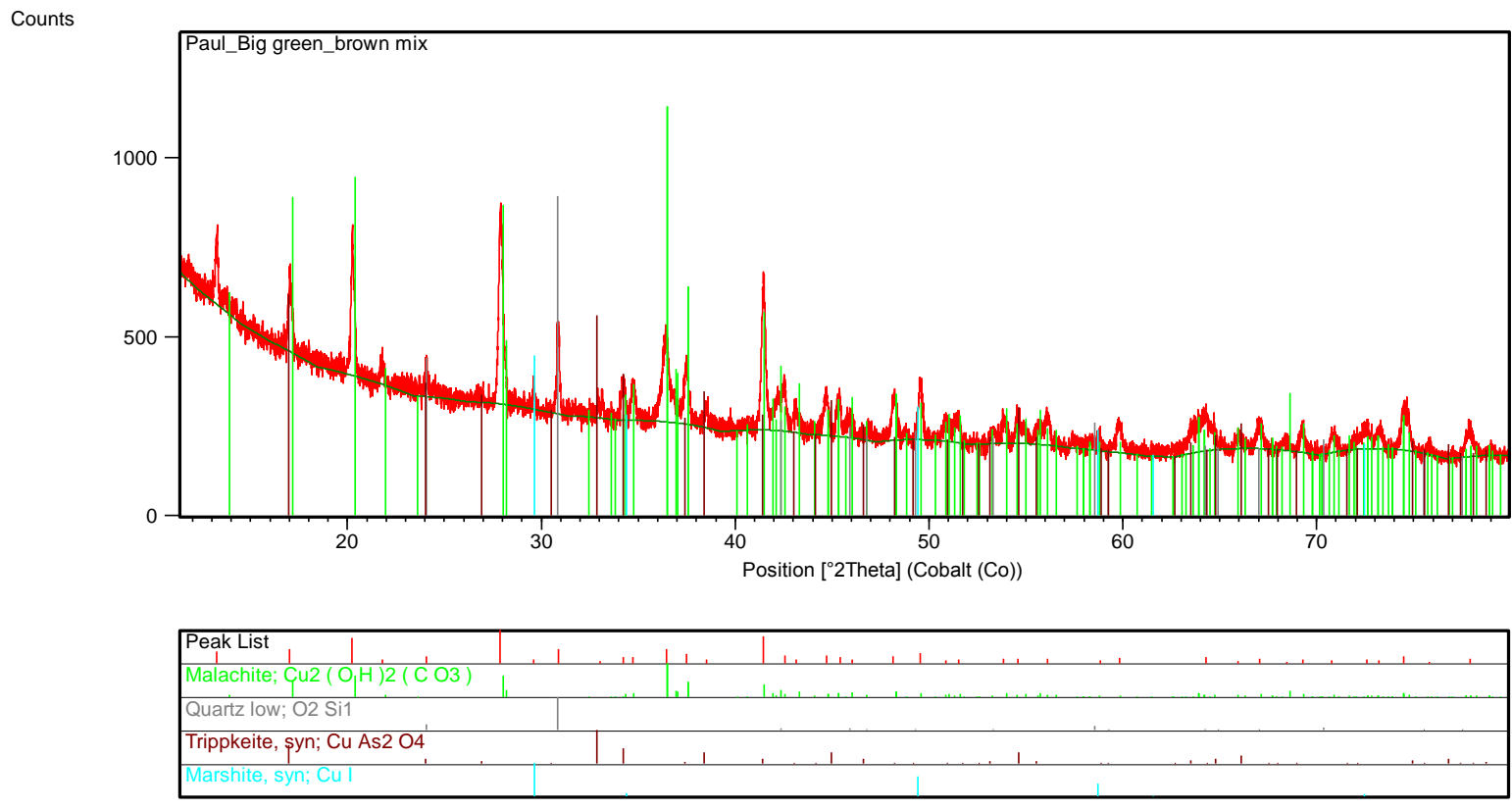

Figure 12. XRD confirmation (by XRD Analytical \& Consulting ) of the presence of trippkeite. 
The minerals so far described from the Albert Silver mine are given in Table 1, the compositions given for these are taken from Fleisher and Mandarino (1995). This study's mineral analyses are referenced as XRD as all those listed were confirmed by XRD-analysis.

Table 1. Mineral occurrences at the Albert Silver mine.

\begin{tabular}{|c|c|c|}
\hline Mineral & Composition & Reference \\
\hline Acanthite & $\mathrm{Ag}_{2} \mathrm{~S}$ & Cairncross \& Dixon, 1995 \\
\hline Anglesite & $\mathrm{PbSO}_{4}$ & XRD \\
\hline Arsenopyrite & FeAsS & Van Zijl, 1965, Champion 1970, XRD \\
\hline Azurite & $\mathrm{Cu}_{3}{ }^{2+}\left(\mathrm{CO}_{3}\right)_{2}(\mathrm{OH})_{2}$ & Champion 1970 \\
\hline Bornite & $\mathrm{Cu}_{5} \mathrm{FeS}_{4}$ & Van Zijl, 1965, Champion 1970 \\
\hline Brochantite & $\mathrm{Cu}_{4}{ }^{2+}\left(\mathrm{SO}_{4}\right)(\mathrm{OH})_{6}$ & XRD \\
\hline Calcite & $\mathrm{CaCO}_{3}$ & Champion 1970 \\
\hline Cassiterite (adjacent to the copper lode) & $\mathrm{SnO}_{2}$ & Cairncross \& Dixon, 1995 \\
\hline Cerussite & $\mathrm{PbCO}_{3}$ & XRD \\
\hline Chalcanthite & $\mathrm{Cu}^{2+} \mathrm{SO}_{4} .5 \mathrm{H}_{2} \mathrm{O}$ & Champion 1970 \\
\hline Chalcocite & $\mathrm{Cu}_{2} \mathrm{~S}$ & Van Zijl, 1965 \\
\hline Chalcopyrite & $\mathrm{CuFeS}_{2}$ & Van Zijl, 1965, Champion 1970, XRD \\
\hline Chlorite & Group collective name & Champion 1970 \\
\hline Clinoclase & $\mathrm{Cu}_{3}{ }^{2+}\left(\mathrm{AsO}_{4}\right)(\mathrm{OH})_{3}$ & XRD \\
\hline Covellite & $\mathrm{CuS}$ & Champion 1970, XRD \\
\hline Fluorite & $\mathrm{CaF}_{2}$ & Champion 1970 \\
\hline Galena & $\mathrm{PbS}$ & Van Zijl, 1965, Champion 1970 \\
\hline Gold & $\mathrm{Au}$ & $\begin{array}{l}\text { Champion 1970, Cairncross \& Dixon, } \\
1995\end{array}$ \\
\hline $\begin{array}{l}\text { Hematite/Specularite (oxidized } \\
\text { portions of the lode) }\end{array}$ & $\alpha-\mathrm{Fe}_{2} \mathrm{O}_{3}$ & Van Zijl, 1965, Champion 1970, XRD \\
\hline Jamesonite & $\mathrm{Pb}_{4} \mathrm{FeSb}_{6} \mathrm{~S}_{14}$ & Van Zijl, 1965 \\
\hline Libethenite & $\mathrm{Cu}_{2}{ }^{2+}\left(\mathrm{PO}_{4}\right)(\mathrm{OH})$ & Cairncross \& Dixon, 1995 \\
\hline Limonite & $\alpha-\mathrm{Fe}^{3+} \mathrm{O}(\mathrm{OH})$ & Champion 1970 \\
\hline Linarite & $\mathrm{PbCu}^{2+}\left(\mathrm{SO}_{4}\right)(\mathrm{OH})_{2}$ & XRD \\
\hline Lindackerite-type (turquoise blue) & $\mathrm{H}_{2} \mathrm{Cu}_{5}{ }^{2+}\left(\mathrm{AsO}_{4}\right)_{4} \cdot 8-9 \mathrm{H}_{2} \mathrm{O}$ & Champion 1970 \\
\hline Malachite & $\mathrm{Cu}_{2}^{2+}\left(\mathrm{CO}_{3}\right)(\mathrm{OH})_{2}$ & $\begin{array}{l}\text { Champion 1970, Cairncross \& Dixon, } \\
\text { 1995, XRD }\end{array}$ \\
\hline Magnetite & $\mathrm{Fe}^{2+} \mathrm{Fe}_{2}^{3+} \mathrm{O}_{4}$ & Champion 1970 \\
\hline Marshite & $\mathrm{CuI}$ & XRD \\
\hline Metatorbernite & $\mathrm{Cu}^{2+}\left(\mathrm{UO}_{2}\right)_{2}\left(\mathrm{PO}_{4}\right)_{2} .8 \mathrm{H}_{2} \mathrm{O}$ & Cairncross \& Dixon, 1995 \\
\hline Metazeunerite & $\mathrm{Cu}^{2+}\left(\mathrm{UO}_{2}\right)_{2}\left(\mathrm{AsO}_{4}\right)_{2} .8 \mathrm{H}_{2} \mathrm{O}$ & $\begin{array}{l}\text { Champion 1970, Cairncross \& Dixon, } \\
1995\end{array}$ \\
\hline Molybdenite & $\mathrm{MoS}_{2}$ & Champion 1970 \\
\hline Muscovite & $\mathrm{KAl}_{2}\left(\mathrm{Si}_{3} \mathrm{Al}\right) \mathrm{O}_{10}(\mathrm{OH}, \mathrm{F})_{2}$ & XRD \\
\hline Olivenite & $\mathrm{Cu}_{2}^{2+}\left(\mathrm{AsO}_{4}\right)(\mathrm{OH})$ & Cairncross \& Dixon, 1995 \\
\hline Onoratoite & $\mathrm{Sb}_{8} \mathrm{O}_{11} \mathrm{Cl}_{2}$ & XRD \\
\hline Pitchblende & $\mathrm{UO}_{2}$ & Champion 1970 \\
\hline Pyrite & $\mathrm{FeS}_{2}$ & Van Zijl, 1965, Champion 1970 \\
\hline $\begin{array}{l}\text { Quartz (Gangue) } \\
\text { Variety: Jasperoid and Milky }\end{array}$ & $\mathrm{SiO}_{2}$ & Van Zijl, 1965, XRD \\
\hline Siderite & $\mathrm{Fe}^{2+} \mathrm{CO}_{3}$ & Van Zijl, 1965 \\
\hline Silver & $\mathrm{Ag}$ & Cairncross \& Dixon, 1995 \\
\hline Sphalerite & $(\mathrm{Zn}, \mathrm{Fe}) \mathrm{S}$ & Van Zijl, 1965, Champion 1970 \\
\hline Sulphantimonides & Yellow complex $\mathrm{Bi}, \mathrm{As}, \mathrm{Sb}, \mathrm{Pb}$ oxides & Champion 1970 \\
\hline Tennantite & $(\mathrm{Cu}, \mathrm{Ag}, \mathrm{Fe}, \mathrm{Zn})_{12} \mathrm{As}_{4} \mathrm{~S}_{13}$ & Cairncross \& Dixon, 1995, XRD \\
\hline Tetrahedrite & $(\mathrm{Cu}, \mathrm{Fe}, \mathrm{Ag}, \mathrm{Zn})_{12} \mathrm{Sb}_{4} \mathrm{~S}_{13}$ & $\begin{array}{l}\text { Van Zijl, 1965, Champion 1970, } \\
\text { Cairncross \& Dixon, } 1995\end{array}$ \\
\hline Torbernite & $\mathrm{Cu}^{2+}\left(\mathrm{UO}_{2}\right)_{2}\left(\mathrm{PO}_{4}\right)_{2} \cdot 8-12 \mathrm{H}_{2} \mathrm{O}$ & Cairncross \& Dixon, 1995 \\
\hline Trippkeite & $\mathrm{CuAs}_{2} \mathrm{O}_{4}$ & XRD \\
\hline Uraninite & $\mathrm{UO}_{2}$ & Cairncross \& Dixon, 1995 \\
\hline Zeunerite & $\mathrm{Cu}^{2+}\left(\mathrm{UO}_{2}\right)_{2}\left(\mathrm{AsO}_{4}\right)_{2} \cdot 10-16 \mathrm{H}_{2} \mathrm{O}$ & Cairncross \& Dixon, 1995 \\
\hline
\end{tabular}




\section{ACKNOWLEDGEMENTS}

William W Besse for his efforts in providing the locality map and plan of the underground workings based on sketches.

\section{REFERENCES}

Cairncross, B. 1991. The Messina mining district, South Africa. Mineralogical Record 22 (3): 187199.

Cairncross, B. and Dixon, R. 1995. Minerals of South Africa. The Geological Society of South Africa, Linden, Johannesburg, 290 p.

Champion, A.T. 1970. The Mineralogy and Related Geology of the Albert Silver Mine,

Bronkhorstspruit - Transvaal. Unpublished M.Sc. thesis. University of Natal, Durban 89 p.

Favreau, G., Dietrich, J.E., Meisser, N., Brugger, J., Haddouch, L.A. and Maacha, L.. 2007. Famous mineral localities: Bou Azzer, Morocco. Mineralogical Record 38 (5): 345-407.

Fleisher, M. and Mandarino, J.A. 1995. Glossary of Mineral Species, 1995. Mineralogical Record, Tucson, $280 \mathrm{p}$.

Martini, J.E.J. and Vorster, C.J. 1994. The Metallogeny of the Pretoria Area. Explanation of Metallogenic Sheet 2528, Geological Survey of South Africa. Government Printer, Pretoria, 58 p.

Park, C.F. and McDiarmid, R.A. 1963. Ore Deposits. Freeman, 530 p.

Reeks, G.W. 2012. A History of Silver Mining in the greater Pretoria region, 1885 - 1999.

Unpublished MA dissertation, University of South Africa, Pretoria, 213 p.

Robb, L.J., Robb, V.M. and Walraven, F. 1994. The Albert Silver Mine revisited: towards a model for polymetalic mineralization in granites of the Bushveld Complex, South Africa. In Exploration and Mining Geology 3: 247-262.

Van Zijl, J.S.V. 1965. A Geological-Geophysical Investigation of the Albert Silver Mine North of Bronkhorstspruit, Transvaal. Bulletin 43 of the Geological Survey of South Africa. Government Printer, Pretoria, 84 p. 